\title{
Occurrence of Cryptosporidium Oocysts in Leisure Pools in the UK, 2017, and Modelling of Oocyst Contamination Events
}

\author{
Rachel M. Chalmers ${ }^{1,2, *}$, Lester P. Simmonds ${ }^{3}$, Martin Wood ${ }^{3}$, Megan Luxford ${ }^{4}$, Rob Miller ${ }^{5}$ and Rob Johnston ${ }^{6}$ \\ 1 Cryptosporidium Reference Unit, Public Health Wales Microbiology and Health Protection, \\ Singleton Hospital, Swansea SA2 8QA, UK \\ 2 Swansea University Medical School, Swansea University, Singleton Park, Swansea SA2 8PP, UK \\ 3 Pool Sentry Ltd., Dale Cottage, Stanton Dale, Ashbourne DE6 2BX, UK; lester@poolsentry.co.uk (L.P.S.); \\ martin@poolsentry.co.uk (M.W.) \\ 4 IDEXX Technologies Ltd., Units 1B \& 1C, Newmarket Business Park, Studlands Park Avenue, Newmarket, \\ Suffolk CB8 7ER, UK; Megan-Luxford@idexx.com \\ 5 Latis Scientific Ltd., Unit C1 Acorn Industrial Park, Crayford, Kent DA 1 4AL, UK; \\ Rob.Miller@latisscientific.co.uk \\ 6 Public Health England, Seaton House, London Road, Nottingham NG2 4LA, UK; Rob.Johnston@phe.gov.uk \\ * Correspondence: rachel.chalmers@wales.nhs.uk
}

check for updates

Citation: Chalmers, R.M.; Simmonds, L.P.; Wood, M.; Luxford, M.; Miller, R.; Johnston, R. Occurrence of Cryptosporidium Oocysts in Leisure Pools in the UK, 2017, and Modelling of Oocyst Contamination Events. Water 2021, 13, 1503. https://doi.org/10.3390/ w13111503

Academic Editor: Athena Mavridou

Received: 21 April 2021

Accepted: 26 May 2021

Published: 27 May 2021

Publisher's Note: MDPI stays neutral with regard to jurisdictional claims in published maps and institutional affiliations.

Copyright: (c) 2021 by the authors. Licensee MDPI, Basel, Switzerland. This article is an open access article distributed under the terms and conditions of the Creative Commons Attribution (CC BY) license (https:/ / creativecommons.org/licenses/by/ $4.0 /)$.

\begin{abstract}
Cryptosporidium is a major cause of diarrhoea outbreaks linked to swimming pools, but little is known about the frequency of contamination. The primary aim was to investigate the occurrence and concentration, through sampling and modelling, of Cryptosporidium oocysts in leisure pools. Secondary aims were to compare detections with operational parameters, provide the evidence-base for guidance, and improve sampling capacity and interpretation for public health investigations. Up to 1000 L pool water was sampled during swim sessions once weekly for 10 weeks from 8 August 2017 at six volunteer pools. Oocysts were detected by microscopy in 12/59 (20\%) pool water samples, at least once in each pool; 8/12 (66\%) detections were in August when bather loads were highest. At three pools, $1 \mathrm{~L}$ filter backwash was sampled weekly and oocysts were detected in $2 / 29$ (7\%) samples, following detections in pool water. The probabilities of a bather contaminating the pool ranged from 1 in 1000 to over 1 in 10,000. Monte Carlo analysis showed that when high bather numbers caused contamination on over $70 \%$ of days, multiple events per day were more likely than single events. In these generally well-managed leisure pools, Cryptosporidium risk related to high bather loads. We conclude that public awareness campaigns for bather hygiene, and reminding pool operators of current guidance for managing faecal accidents, should be ahead of peak swim season.
\end{abstract}

Keywords: backwash; cryptosporidium; occurrence; oocyst counts; swimming pool water; probability modelling

\section{Introduction}

The protozoan parasite Cryptosporidium is an important cause of gastroenteritis and the most frequently identified pathogen in outbreaks linked to treated recreational waters, especially "leisure" swimming pools, in the United Kingdom (UK) [1,2] and United States (US) [3]. Cryptosporidium oocysts (4-6 $\mu \mathrm{m}$ diameter) are shed in high numbers in the faeces of symptomatic patients, and to a lesser extent by recuperating patients and asymptomatic carriers. However, there is a significant risk of infection and illness from ingestion of even small numbers of oocysts [4]. The oocyst wall confers high chlorine resistance on the parasite; whereas bacteria and viruses are inactivated in minutes, Cryptosporidium requires up to 10.6 days exposure in water containing $1 \mathrm{mg} / \mathrm{L}$ of residual chlorine at $\mathrm{pH} 7.5,25^{\circ} \mathrm{C}$, to achieve a $3 \log _{10}$ reduction in infectivity [5]. Cryptosporidium control, therefore, necessitates good pool construction, hydraulics, operation and management, prevention of contamination, effective removal of oocysts by optimal filtration, and inactivation by secondary disinfection with ultraviolet (UV) light or ozone [6,7]. 
Although oocyst concentration/L of pool water has been identified as the most influential factor on the probability of infection with Cryptosporidium in swimming pools [8], it is not tested for routinely and there are no quantitative standards. Furthermore, oocyst concentration can also contribute the greatest degree of uncertainty in risk of infection estimates [9]. Detection is dependent on the efficient recovery of oocysts from samples, and oocyst recovery data from the testing laboratory should be included if oocyst concentrations are to be used to infer health risks, to ensure that risk is not underestimated [10].

Few structured, prospective sample surveys of Cryptosporidium in swimming pools have been published and it is difficult to compare results as different sampling frames, methods, detection assays, and outcome measures have been used (Table 1). For example, some report sample prevalence based on the presence/absence of oocysts or Cryptosporidium DNA, while others report oocyst counts by microscopy (Table 1). Standard methods for testing drinking water for Cryptosporidium have been used for pool water but there are no published validation data for this sample type. The published survey data (Table 1) indicate that to quantify risk from Cryptosporidium, pools need to be: (1) sampled repeatedly, or in sufficient numbers, as the parasite may not be present persistently; (2) sampled by passing large volumes of pool water through appropriate filter modules for representative sampling; (3) tested using validated quantification methods; and (4) additionally investigated for appropriate parameters such as bacterial indicator organisms and physiochemical properties to monitor the pool water treatment. Few associations have been reported between pool parameters and Cryptosporidium detections (Table 1), although one study in China reported a strong correlation between parasite detection and urea in pool water [11]. Epidemiological evidence suggests seasonal sampling may be more valuable for infection risk assessment than year-round; swimming pool-related cryptosporidiosis outbreaks are reported most frequently in the summer months (June, July and August) in the US [3] and in the summer and mid-autumn (July through to October) in the UK [1,2]. A study in China reported significantly more samples positive in summer (August) than in spring (May) (Table 1; [11]).

The interpretation of survey data is confounded further by how the numbers of oocysts relate to the risk to bathers; the concentrations of oocysts in pool water are likely to vary widely in time and space, with very high relative concentrations in the vicinity shortly after a faecal release. The volume and movement of water in the pool will affect the extent to which oocysts are diluted and distributed, and filter efficiency will determine removal. For example, for a well-mixed pool with filters that have a $90 \%$ removal efficiency, it is expected that about $57 \%$ of oocysts would be removed in each turnover [12], making the concentration in the pool very dynamic. Hence there is a challenge in assessing the risk to bathers in terms of the peak concentrations that they might have been exposed to on days with detectable contamination.

Currently, there are no published baseline data from structured surveys of Cryptosporidium in swimming pools in the UK and it is not known how frequently oocysts are present or at what concentrations. The primary aim of this study was a longitudinal survey, involving weekly sampling for 10 weeks during late summer/early autumn of 2017, to estimate the background occurrence and concentrations of Cryptosporidium oocysts in leisure pools. The oocyst concentrations in pool water, averaged during sampling over the course of a day of operation, were used to enable proof of concept probabilistic modelling of the likelihood of there being a measurable input of oocysts into the pool during the day, and whether any such inputs were likely to be single or multiple events. A modelling approach was also used to estimate the magnitude of events in terms of oocyst numbers (and the associated peak concentrations) from daily average data taking account of what is known about the dynamics of oocyst numbers in relation to water circulation and filtration [12]. 
Table 1. Published sample surveys for Cryptosporidium in swimming pools.

\begin{tabular}{|c|c|c|c|c|c|c|c|c|c|c|c|c|}
\hline Country & $\begin{array}{l}\text { Venue, Pool } \\
\text { Types and } \\
\text { Numbers }\end{array}$ & $\begin{array}{l}\text { Duration of } \\
\text { Study }\end{array}$ & $\begin{array}{l}\text { Sampling } \\
\text { Frequency }\end{array}$ & $\begin{array}{l}\text { Sample } \\
\text { Type }\end{array}$ & $\begin{array}{l}\text { Collection } \\
\text { Method }\end{array}$ & $\begin{array}{c}\text { Sample } \\
\text { Volume } \\
\text { Processed }\end{array}$ & $\begin{array}{c}\text { Oocyst } \\
\text { Capture and } \\
\text { Detection } \\
\text { Method }\end{array}$ & $\begin{array}{l}\text { Pools } \\
\text { Positive }\end{array}$ & $\begin{array}{l}\text { Samples } \\
\text { Positive }\end{array}$ & $\begin{array}{c}\text { Oocyst Counts } \\
\text { Reported }\end{array}$ & $\begin{array}{l}\text { Key findings } \\
\text { Relating to } \\
\text { Cryptosporidium }\end{array}$ & Reference \\
\hline France & $\begin{array}{l}4 \text { public pools } \\
\text { used for babies } \\
\text { and children, } \\
1 \text { private club } \\
\text { adults pool }\end{array}$ & $\begin{array}{l}\text { November } \\
1998 \text { to } \\
\text { January } 2000\end{array}$ & $\begin{array}{l}8 \times \text { over } \\
1 \text { year }\end{array}$ & $\begin{array}{l}\text { Pool } \\
\text { water }\end{array}$ & $\begin{array}{l}\text { Capsule } \\
\text { filter }\end{array}$ & $300-600 \mathrm{~L}$ & $\begin{array}{l}\text { Gradient } \\
\text { flotation; } \\
\text { IFM }\end{array}$ & $1 / 5(20 \%)$ & $1 / 40(3 \%)$ & $0.6 / 100 \mathrm{~L}$ & $\begin{array}{l}\text { Detection was in the } \\
\text { private club } \\
\text { adults pool }\end{array}$ & [13] \\
\hline Greece & $\begin{array}{l}3 \text { public indoor } \\
\text { pools: adult, } \\
\text { children's and } \\
\text { hydrotherapy }\end{array}$ & $\begin{array}{l}\text { October } 1998 \\
\quad \text { to } \\
\text { March } 1999\end{array}$ & $\begin{array}{l}3 \times \text { over } \\
5 \text { months }\end{array}$ & $\begin{array}{c}\text { Pool } \\
\text { water }\end{array}$ & $\begin{array}{l}\text { Wound } \\
\text { filter }\end{array}$ & $500-1000 \mathrm{~L}$ & $\begin{array}{l}\text { Gradient } \\
\text { flotation; } \\
\text { IFM }\end{array}$ & $1 / 3(33 \%)$ & $1 / 9(11 \%)$ & $0.3 / 100 \mathrm{~L}$ & $\begin{array}{l}\text { Detection was in the } \\
\text { adult pool }\end{array}$ & [14] \\
\hline \multirow[t]{3}{*}{$\begin{array}{l}\text { The } \\
\text { Netherlands }\end{array}$} & $\begin{array}{c}7 \text { filters at } \\
5 \text { public pool } \\
\text { complexes }\end{array}$ & $\begin{array}{l}\text { May } 2000 \text { to } \\
\text { June } 2001\end{array}$ & Biweekly & $\begin{array}{l}\text { Back- } \\
\text { wash }\end{array}$ & Grab & $1-25 \mathrm{~L}$ & $\begin{array}{l}\text { Calcium } \\
\text { carbonate } \\
\text { flocculation; } \\
\text { IMS; IFM }\end{array}$ & $7 / 7$ filters & $9 / 150(6 \%)$ & 0.11 to $17 / \mathrm{L}$ & $\begin{array}{l}\text { A high proportion of } \\
\text { oocysts were } \\
\text { damaged or empty }\end{array}$ & [15] \\
\hline & 4 toddler pools & $\begin{array}{l}\text { June to } \\
\text { September } \\
2001\end{array}$ & Weekly & $\begin{array}{c}\text { Pool } \\
\text { water }\end{array}$ & $\begin{array}{l}\text { Capsule } \\
\text { filter }\end{array}$ & $200-400 \mathrm{~L}$ & IMS; IFM & $0 / 4$ & $0 / 14$ & 0 & $\begin{array}{l}\text { Regular reporting of } \\
\text { faecal accidents }\end{array}$ & \\
\hline & 1 learner pool & $\begin{array}{l}\text { June to } \\
\text { September } \\
2001\end{array}$ & Weekly & $\begin{array}{l}\text { Pool } \\
\text { water }\end{array}$ & $\begin{array}{l}\text { Capsule } \\
\text { filter }\end{array}$ & $1000 \mathrm{~L}$ & IMS; IFM & $1 / 1(100 \%)$ & $7 / 9(78 \%)$ & 0.004 to $2.31 / \mathrm{L}$ & $\begin{array}{l}\text { Faecal accident; } \\
\text { filter cracks }\end{array}$ & \\
\hline Italy & 10 public pools & $\begin{array}{c}\text { May-August } \\
2003\end{array}$ & $\begin{array}{l}\text { Over two } \\
\text { months }\end{array}$ & $\begin{array}{l}\text { Back- } \\
\text { wash }\end{array}$ & Grab & $1.1-1.3 \mathrm{~L}$ & IMS; IFM & $1 / 3(33 \%)$ & $1 / 3(33 \%)$ & 8/1.3 L & $\begin{array}{l}\text { Bather numbers } \\
\text { reported. Additional } \\
\text { testing by PCR was } \\
\text { negative for } \\
\text { Cryptosporidium but } \\
\text { positive for } \\
\text { protozoan rDNA }\end{array}$ & [16] \\
\hline Italy & Not stated & 2001-2002 & not stated & $\begin{array}{c}\text { Pool } \\
\text { water }\end{array}$ & $\begin{array}{l}\text { Capsule } \\
\text { filter }\end{array}$ & $500 \mathrm{~L}$ & IMS; IFM & $1 / 1$ & $1 / 11(9 \%)$ & $4 \times 10^{-2 / 100 \mathrm{~L}}$ & $\begin{array}{l}\text { Detection was in an } \\
\text { outdoor pool }\end{array}$ & [17] \\
\hline Italy & 7 public pools & $\begin{array}{l}\text { May } 2004 \text { to } \\
\text { August } 2005\end{array}$ & $\begin{array}{l}\text { in some } \\
\text { months }\end{array}$ & $\begin{array}{c}\text { Pool } \\
\text { water }\end{array}$ & Grab & $20 \mathrm{~L}$ & $\begin{array}{l}\text { Centrifugation; } \\
\text { IFM }\end{array}$ & $2 / 7(29 \%)$ & $6 / 21(29 \%)$ & $0.5-2 / \mathrm{L}$ & $\begin{array}{l}5 \text { detections were at } \\
\text { one pool complex. } \\
\text { Bather numbers } \\
\text { reported. }\end{array}$ & [18] \\
\hline Greece & $\begin{array}{c}5 \text { pools: } \\
3 \text { public indoor } \\
\text { and } 2 \text { private } \\
\text { outdoor pools }\end{array}$ & 1997-2005 & $\begin{array}{l}\text { 2xmonthly } \\
\text { then monthly }\end{array}$ & $\begin{array}{l}\text { Pool } \\
\text { water }\end{array}$ & $\begin{array}{l}\text { Wound } \\
\text { filter }\end{array}$ & $1000 \mathrm{~L}$ & $\begin{array}{l}\text { Gradient } \\
\text { flotation; } \\
\text { IFM }\end{array}$ & $0 / 5$ & $0 / 462$ & & $\begin{array}{l}\text { Bather numbers } \\
\text { reported. }\end{array}$ & [19] \\
\hline USA & $\begin{array}{l}160 \text { public pool } \\
\text { filters }\end{array}$ & $\underset{2006}{\mathrm{Aug}-\mathrm{Oct}}$ & $\begin{array}{l}\text { Once per } \\
\text { pool }\end{array}$ & $\begin{array}{l}\text { Back- } \\
\text { wash }\end{array}$ & Grab & $1 \mathrm{~L}$ & $\begin{array}{l}\text { Calcium } \\
\text { carbonate } \\
\text { flocculation; } \\
\text { PCR }\end{array}$ & $3 / 160(2 \%)$ & $3 / 160(2 \%)$ & $\mathrm{n} / \mathrm{a}$ & $\begin{array}{l}\text { Detections were in } \\
\text { small community } \\
\text { pools with 1-75 } \\
\text { bathers/week used } \\
\text { by children } \\
\text { and adults }\end{array}$ & [20] \\
\hline
\end{tabular}


Table 1. Cont

\begin{tabular}{|c|c|c|c|c|c|c|c|c|c|c|c|c|}
\hline Country & $\begin{array}{l}\text { Venue, Pool } \\
\text { Types and } \\
\text { Numbers }\end{array}$ & $\begin{array}{l}\text { Duration of } \\
\text { Study }\end{array}$ & $\begin{array}{l}\text { Sampling } \\
\text { Frequency }\end{array}$ & $\begin{array}{l}\text { Sample } \\
\text { Type }\end{array}$ & $\begin{array}{l}\text { Collection } \\
\text { Method }\end{array}$ & $\begin{array}{l}\text { Sample } \\
\text { Volume } \\
\text { Processed }\end{array}$ & $\begin{array}{l}\text { Oocyst } \\
\text { Capture and } \\
\text { Detection } \\
\text { Method }\end{array}$ & $\begin{array}{c}\text { Pools } \\
\text { Positive }\end{array}$ & $\begin{array}{l}\text { Samples } \\
\text { Positive }\end{array}$ & $\begin{array}{l}\text { Oocyst Counts } \\
\text { Reported }\end{array}$ & $\begin{array}{l}\text { Key findings Relating } \\
\text { to Cryptosporidium }\end{array}$ & Reference \\
\hline Egypt & $\begin{array}{l}5 \text { swimming } \\
\text { pools }\end{array}$ & 6 months & $\begin{array}{l}\text { Monthly over } \\
6 \text { months }\end{array}$ & $\begin{array}{c}\text { Pool } \\
\text { water }\end{array}$ & $\begin{array}{c}\text { not } \\
\text { stated }\end{array}$ & not stated & $\begin{array}{l}\text { Membrane } \\
\text { filtration; sed- } \\
\text { imentation; } \\
\text { acid-fast } \\
\text { microscopy }\end{array}$ & $1 / 5(20 \%)$ & $1 / 30(3 \%)$ & not stated & $\begin{array}{l}\text { Significant association } \\
\text { between poor water } \\
\text { quality and bather load; } \\
\text { not investigated for } \\
\text { Cryptosporidium }\end{array}$ & [21] \\
\hline Malaysia & $\begin{array}{l}1 \text { swimming } \\
\text { pool }\end{array}$ & $\begin{array}{l}\text { Oct-Dec } \\
2011\end{array}$ & & $\begin{array}{l}\text { Pool } \\
\text { water }\end{array}$ & Grab & $10 \mathrm{~L}$ & $\begin{array}{l}\text { Membrane } \\
\text { filtration; } \\
\text { IMS; IFM }\end{array}$ & $0 / 1$ & $0 / 1$ & 0 & & [22] \\
\hline The Philippines & $\begin{array}{l}3 \text { swimming } \\
\text { pools }\end{array}$ & Oct 2012 & $\begin{array}{l}\text { Once per } \\
\text { pool }\end{array}$ & $\begin{array}{l}\text { Pool } \\
\text { water }\end{array}$ & Grab & $10 \mathrm{~L}$ & $\begin{array}{l}\text { Membrane } \\
\text { filtration; } \\
\text { IMS; IFM }\end{array}$ & $1 / 3(33 \%)$ & $1 / 3(33 \%)$ & $0.6 / \mathrm{L}$ & & [23] \\
\hline \multirow[t]{2}{*}{ Belgium } & $\begin{array}{l}20 \text { public pools: } \\
\text { indoors and } \\
\text { outdoors }\end{array}$ & $\begin{array}{l}\text { March-Oct } \\
2010\end{array}$ & not stated & $\begin{array}{l}\text { Pool } \\
\text { water }\end{array}$ & $\begin{array}{l}\text { Filter } \\
\text { module }\end{array}$ & $60 \mathrm{~L}$ & IMS; IFM & $0 / 20$ & 0 & & & [24] \\
\hline & $\begin{array}{l}16 \text { public pool } \\
\text { filters: indoors } \\
\text { and outdoors }\end{array}$ & $\begin{array}{l}\text { March-Oct } \\
2010\end{array}$ & not stated & $\begin{array}{l}\text { Back- } \\
\text { wash }\end{array}$ & Grab & $2-60 \mathrm{~L}$ & IMS; IMF & $2 / 16(13 \%)$ & 2 & $\begin{array}{l}0.03 \text { and } 0.23 \\
\text { per } \mathrm{L}\end{array}$ & & [24] \\
\hline China & 35 public pools & $\begin{array}{l}\text { May and } \\
\text { August } 2015\end{array}$ & $\begin{array}{l}\text { Most pools } \\
\text { twice }\end{array}$ & $\begin{array}{l}\text { Pool } \\
\text { water }\end{array}$ & Grab & $10 \mathrm{~L}$ & $\begin{array}{l}\text { Flotation; } \\
\text { IFM }\end{array}$ & $5 / 35(14 \%)$ & $10 / 60(17 \%)$ & $\begin{array}{l}0-4, \text { mean } 0.30 \\
\text { oocysts } / 10 \mathrm{~L}\end{array}$ & \multirow[t]{3}{*}{$\begin{array}{l}\text { The sample positivity } \\
\text { rate was higher in } \\
\text { August }(24.2 \%) \text { than in } \\
\text { May }(7.4 \%) \text {. A strong } \\
\text { correlation reported } \\
\text { between parasite } \\
\text { detection and urea }\end{array}$} & [11] \\
\hline USA & $\begin{array}{l}127 \text { public } \\
\text { pools; indoor } \\
\text { and outdoor }\end{array}$ & $\begin{array}{l}\text { July- } \\
\text { August } \\
2012\end{array}$ & $\begin{array}{c}\text { Most pools } \\
\text { once, } \\
30 \text { pools }> \\
\text { once }\end{array}$ & Backwash & Grab & $800 \mathrm{~m}$ & $\begin{array}{c}\text { PEG } \\
\text { precipitation; } \\
\text { PCR }\end{array}$ & 1/127 (1\%) & $1 / 160(1 \%)$ & $\mathrm{n} / \mathrm{a}$ & & [25] \\
\hline China & $\begin{array}{l}39 \text { public pools, } \\
\text { all outdoors }\end{array}$ & $\begin{array}{l}\text { June to } \\
\text { September } \\
2013\end{array}$ & not stated & $\begin{array}{l}\text { Pool } \\
\text { water }\end{array}$ & Grab & $50 \mathrm{~L}$ & $\begin{array}{l}\text { Hollow fibre } \\
\text { ultrafiltra- } \\
\text { tion IMS; } \\
\text { IFM }\end{array}$ & $3 / 39(8 \%)$ & 3 & $\begin{array}{l}0.03-0.14 \\
\text { oocysts/L }\end{array}$ & & [26] \\
\hline Spain & $\begin{array}{l}21 \text { indoor } \\
\text { heated public } \\
\text { pools in } \\
5 \text { towns }\end{array}$ & Not stated & Once & $\begin{array}{c}\text { Pool } \\
\text { water }\end{array}$ & Grab & $10 \mathrm{~L}$ & $\begin{array}{l}\text { Calcium } \\
\text { carbonate } \\
\text { flocculation; } \\
\text { IMS; mZN }\end{array}$ & $5 / 21(24 \%)$ & $5 / 21(24 \%)$ & 3-13 oocysts/L & $\begin{array}{c}\text { No statistically } \\
\text { significant associations } \\
\text { but pools with fewer } \\
\text { users }(<100) \text { wereall } \\
\text { negative, whereas pools } \\
\text { with a medium user } \\
\text { frequency }(100-500) \text { had } \\
\text { the highest } \\
\text { positivity rate. }\end{array}$ & [27] \\
\hline
\end{tabular}

IFM = immunofluorescence microscopy; IMS = immunomagnetic separation; PCR = polymerase chain reaction; $\mathrm{mZN}$ = modified Ziehl-Neelsen. 
Secondary aims were to provide validation and oocyst recovery data for the methods used for testing swimming pool water and filter backwash, compare detections with chemical, bacterial and operational parameters, provide an evidence-base for guidance, improve sampling capacity and interpretation for public health investigations, and provide data that could contribute to quantitative microbial risk assessment (QMRA).

\section{Materials and Methods}

\subsection{Swimming Pool Recruitment and Description}

A convenience sample of six volunteer swimming pools was recruited to the study, three in England, two in Wales and one in Scotland. Table 2 provides the details of each pool. All were free-form leisure pools of varying depth, with features such as slides, wave machines, or lazy rivers. Four were exclusively indoor pools and two had a linked, outdoor area. Two were set at large residential holiday parks and four served local communities. Five were filled solely from the mains water supply and one supplemented with an onsite borehole. Two indoor pools were disinfected with sodium bromide plus sodium hypochlorite, and four pools (two indoor and two incorporating outdoor areas) with sodium or calcium hypochlorite. None used cyanuric acid to limit natural UV light degradation of chlorine. Five pools had medium velocity $(<25 \mathrm{~m} / \mathrm{h})$ sand filters and one had high-velocity filters filled with glass. All pools used polyaluminium chloride (PAC) as a coagulant. Three pools (including that with high-velocity filters) had secondary disinfection in the form of UV light.

All pools were inspected for construction, operation and management features ahead of sampling, using the checklist available elsewhere online as Appendix 1 of the "Guidance for the investigation of Cryptosporidium linked to swimming pools" found at www. publichealthwales.org/cryptopoolguidance (accessed on 23 March 2021).

\subsection{Swimming Pool Water and Filter Backwash Sampling}

High volume pool water samples were collected on the same day each week for ten weeks from 8 August 2017. At each pool, a gate valve was installed in the return pipework from the swimming pool tank to the filters, after the coarse strainers and circulation pumps. A Cryptosporidium sampling rig was constructed for each pool comprising, sequentially, a non-return connector, $13 \mathrm{~mm}$ internal diameter flexible PVC hosing, an open-cell reticulated polyurethane filter module in a filter housing (Filta-Max xpress ${ }^{\mathrm{TM}}$, IDEXX Technologies Ltd., Newmarket, UK), a flow meter (Gardena Water Smart 818, Gardena, Ulm, Germany) and a waste hose. Up to $1000 \mathrm{~L}$ water was sampled at a maximum flow rate of $2 \mathrm{~L} / \mathrm{min}$. Sampling started when the pools opened in the morning and continued for a minimum of $8 \mathrm{~h}$, and a maximum of $24 \mathrm{~h}$. This enabled sampling through and following peak daily use at each pool.

At three of the pools (D, E, and F) it was possible to also sample $1 \mathrm{~L}$ of the initial filter backwash. This was done after the end of the swim session and after completion of pool water sampling, using a single screw cap sample bottle. Filta-Max xpress $^{\mathrm{TM}}$ filter modules and backwash samples were transported with ice packs for delivery the next day to the laboratory (IDEXX Technologies Ltd., Newmarket, UK).

To monitor the management and control of disinfection, $250 \mathrm{~mL}$ water samples were collected for bacteriological testing aseptically in sodium thiosulphate by immersion at 200-400 mm below the surface of each pool [28] at around mid-day on the day of Cryptosporidium sampling and transported with an ice pack for delivery next day to the laboratory (Latis Scientific, Crayford, UK). The contents were temperature checked on arrival to ensure $<8{ }^{\circ} \mathrm{C}$ and tested within $24 \mathrm{~h}$ of collection.

Water quality was monitored by sampling at the same time and depth and tested using the pool's own portable devices for $\mathrm{pH}$, residual free chlorine, temperature, and total dissolved solids. Turbidity was measured using devices provided for the project (TB210IR Handheld Turbidity Meter, The Tintometer Ltd., Amesbury, UK). 
Table 2. Characteristics of the leisure pools sampled.

\begin{tabular}{|c|c|c|c|c|c|c|c|c|c|c|}
\hline \multirow[b]{2}{*}{$\begin{array}{c}\text { Pool } \\
\text { Location }\end{array}$} & \multirow[b]{2}{*}{$\begin{array}{c}\text { Premises, } \\
\text { Description, and } \\
\text { Date Opened }\end{array}$} & \multicolumn{9}{|c|}{ Details of the Pool Sampled (Other Pools and Treatment May be Present on Site) } \\
\hline & & $\begin{array}{l}\text { Pool Water Volume, } \\
\text { Shape and Features }\end{array}$ & $\begin{array}{l}\text { Water } \\
\text { Supply }\end{array}$ & $\begin{array}{l}\text { Turnover } \\
\text { Period (h) }\end{array}$ & $\begin{array}{l}\text { Disinfection } \\
\text { and Target } \\
\text { Free Chlorine } \\
\text { Residual }\end{array}$ & Target $\mathrm{pH}$ & $\begin{array}{l}\text { Target } \\
\text { Temp } \\
{ }^{\circ} \mathrm{C}\end{array}$ & $\begin{array}{c}\text { Secondary } \\
\text { Disinfection }\end{array}$ & $\begin{array}{c}\text { Filtration and } \\
\text { Coagulation }\end{array}$ & $\begin{array}{c}\text { Backwash } \\
\text { Regime }\end{array}$ \\
\hline $\begin{array}{c}\text { A } \\
\text { England }\end{array}$ & $\begin{array}{c}\text { Community leisure } \\
\text { centre complex of } \\
3 \text { main pools with } \\
\text { slides and paddling } \\
\text { pools linked to the } \\
\text { free form } \\
\text { leisure pool. } \\
1990\end{array}$ & $\begin{array}{l}360 \mathrm{~m}^{3} \\
\text { Freeform, indoor pool } \\
\text { with water slides, } \\
\text { wild water, geyser, } \\
\text { water cannons and } \\
\text { wave machine. }\end{array}$ & Mains & 1.5 & $\begin{array}{l}\text { Sodium } \\
\text { bromide plus } \\
\text { sodium } \\
\text { hypochlorite } \\
2.5 \mathrm{mg} / \mathrm{L}\end{array}$ & 8.0 & 30.5 & None & $\begin{array}{l}4 \text { medium-rate } \\
\text { sand filters, } \\
\text { continuously dosed } \\
\text { PAC coagulation. }\end{array}$ & $\begin{array}{l}\text { Scheduled twice } \\
\text { weekly and as } \\
\text { pressure } \\
\text { differentials } \\
\text { dictate. }\end{array}$ \\
\hline $\begin{array}{c}\text { B } \\
\text { England }\end{array}$ & $\begin{array}{c}\text { Holiday park } \\
\text { aquatic centre } \\
\text { complex with } \\
8 \text { pools. } \\
1988\end{array}$ & $\begin{array}{l}1497 \mathrm{~m}^{3} \\
\text { Freeform, indoor and } \\
\text { outdoor pool with } \\
\text { wave pool, whirlpool, } \\
\text { rapids, grotto pool, } \\
\text { water cannon, sprays, } \\
\text { fountain, geysers, } \\
\text { bubble seats. }\end{array}$ & $\begin{array}{c}\text { Mains and } \\
\text { borehole }\end{array}$ & 1.58 & $\begin{array}{l}\text { Sodium } \\
\text { bromide plus } \\
\text { sodium } \\
\text { hypochlorite } \\
1-3 \mathrm{mg} / \mathrm{L}\end{array}$ & $7.4-8.2$ & 30 & None & $\begin{array}{l}12 \text { medium-rate } \\
\text { sand filters, } \\
\text { continuously dosed } \\
\text { PAC coagulation. }\end{array}$ & $\begin{array}{l}\text { Scheduled every } \\
4 \text { days and as } \\
\text { pressure } \\
\text { differentials } \\
\text { dictate. }\end{array}$ \\
\hline $\begin{array}{c}\text { C } \\
\text { Wales }\end{array}$ & $\begin{array}{c}\text { Community leisure } \\
\text { centre complex of } \\
3 \text { pools. } \\
2008\end{array}$ & $\begin{array}{c}85.8 \mathrm{~m}^{3} \text { Free form, } \\
\text { indoor pool with } \\
\text { slide, splashdown, } \\
\text { mushroom spray } \\
\text { feature, } \\
\text { whirlpool area. }\end{array}$ & Mains & NA & $\begin{array}{l}\text { Chlorine } \\
1.5 \mathrm{mg} / \mathrm{L}\end{array}$ & 7.4 & $30-32$ & UV light & $\begin{array}{l}2 \text { high-rate, glass } \\
\text { filters continuously } \\
\text { dosed PAC } \\
\text { coagulation. }\end{array}$ & $\begin{array}{l}\text { Scheduled once } \\
\text { weekly and as } \\
\text { pressure } \\
\text { differentials } \\
\text { dictate. }\end{array}$ \\
\hline $\begin{array}{c}\text { D } \\
\text { Scotland }\end{array}$ & $\begin{array}{c}\text { Community leisure } \\
\text { centre complex of } \\
3 \text { pools. } \\
1998\end{array}$ & $\begin{array}{l}498 \mathrm{~m}^{3} \\
\text { Freeform, indoor and } \\
\text { outdoor pool with } \\
\text { wild water, fan spray, } \\
\text { slides, water cannon, } \\
\text { waterfall. }\end{array}$ & Mains & 2.75 & $\begin{array}{c}\text { Sodium } \\
\text { hypochlorite } \\
1.5 \mathrm{mg} / \mathrm{L}\end{array}$ & $7.2-7.6$ & $29-31$ & UV light & $\begin{array}{l}5 \text { medium-rate sand } \\
\text { filters continuously } \\
\text { dosed PAC } \\
\text { coagulation. } \\
\text { Variable speed } \\
\text { circulation } \\
\text { pumps used. }\end{array}$ & $\begin{array}{l}\text { Scheduled once } \\
\text { weekly and as } \\
\text { pressure } \\
\text { differentials } \\
\text { dictate. }\end{array}$ \\
\hline
\end{tabular}


Table 2. Cont.

\begin{tabular}{|c|c|c|c|c|c|c|c|c|c|c|}
\hline \multirow[b]{2}{*}{$\begin{array}{c}\text { Pool } \\
\text { Location }\end{array}$} & \multirow[b]{2}{*}{$\begin{array}{c}\text { Premises, } \\
\text { Description, and } \\
\text { Date Opened }\end{array}$} & \multicolumn{9}{|c|}{ Details of the Pool Sampled (Other Pools and Treatment May be Present on Site) } \\
\hline & & $\begin{array}{l}\text { Pool Water Volume, } \\
\text { Shape and Features }\end{array}$ & $\begin{array}{l}\text { Water } \\
\text { Supply }\end{array}$ & $\begin{array}{l}\text { Turnover } \\
\text { Period (h) }\end{array}$ & $\begin{array}{l}\text { Disinfection } \\
\text { and Target } \\
\text { Free Chlorine } \\
\text { Residual }\end{array}$ & Target $\mathrm{pH}$ & $\begin{array}{l}\text { Target } \\
\text { Temp } \\
{ }^{\circ} \mathrm{C}\end{array}$ & $\begin{array}{c}\text { Secondary } \\
\text { Disinfection }\end{array}$ & $\begin{array}{l}\text { Filtration and } \\
\text { Coagulation }\end{array}$ & $\begin{array}{l}\text { Backwash } \\
\text { Regime }\end{array}$ \\
\hline $\begin{array}{c}\mathrm{E} \\
\text { Wales }\end{array}$ & $\begin{array}{c}\text { Community leisure } \\
\text { centre complex of } \\
3 \text { pools. } \\
2008\end{array}$ & $\begin{array}{c}1325 \mathrm{~m}^{3} \\
\text { Freeform, indoor pool } \\
\text { with wave machine, } \\
\text { slides, sprays, rapids, } \\
\text { water cannon, air } \\
\text { geyser, } \\
\text { whirlpool area. }\end{array}$ & Mains & NA & $\begin{array}{c}\text { Calcium } \\
\text { hypochlorite } \\
1.2 \mathrm{mg} / \mathrm{L}\end{array}$ & 7.25 & 31 & UV light & $\begin{array}{l}9 \text { sand and pea } \\
\text { gravel medium-rate } \\
\text { filters continuously } \\
\text { dosed PAC } \\
\text { coagulation. } \\
\text { Variable speed } \\
\text { circulation pumps } \\
\text { used. }\end{array}$ & $\begin{array}{c}\text { Scheduled 18-day } \\
\text { cycle reduced to } 9 \\
\text { or } 5 \text { days in busy } \\
\text { periods, and as } \\
\text { pressure } \\
\text { differentials } \\
\text { dictate. }\end{array}$ \\
\hline $\begin{array}{c}\mathrm{F} \\
\text { England }\end{array}$ & $\begin{array}{c}\text { Holiday park } \\
\text { aquatic centre } \\
\text { complex of } 6 \text { pools. } \\
\text { 1980s }\end{array}$ & $\begin{array}{l}299 \mathrm{~m}^{3} \\
\text { Freeform indoor and } \\
\text { outdoor pool } \\
\text { with slide. }\end{array}$ & Mains & 2.15 & $\begin{array}{l}\text { Sodium } \\
\text { hypochlorite } \\
1-3 \mathrm{mg} / \mathrm{L}\end{array}$ & $7.2-7.4$ & $27-30$ & None & $\begin{array}{l}3 \text { medium-rate } \\
\text { sand filters, } \\
\text { continuously dosed } \\
\text { PAC coagulation. }\end{array}$ & $\begin{array}{l}\text { Scheduled once } \\
\text { weekly and as } \\
\text { pressure } \\
\text { differentials } \\
\text { dictate. }\end{array}$ \\
\hline
\end{tabular}


A standardised form (Supplementary Materials Figure S1) was used to collect Cryptosporidium and bacteriological sampling parameters, physical-chemical properties, and daily bather numbers. Information about faecal accidents, arising from the observation of stools in the pool in the seven days preceding sampling, was also collected.

\subsection{Cryptosporidium Analysis}

Cryptosporidium oocysts in pool water samples were enumerated by standard methods [29] based on elution from the filter, centrifugation, immunomagnetic separation (IMS) (Dynabeads ${ }^{\mathrm{TM}}$ anti-Cryptosporidium, Applied Biosystems, Thermo Fisher Scientific Baltics UAB, Vilnius, Lithuania) and immunofluorescence microscopy (IFM) (EasyStain, BTF, North Ryde, Australia or Crypto-Cel, TCS BioSciences, Botolph Claydon, UK) according to manufacturer's instructions. Additional nucleic acid staining was performed with 4',6-Diamidino-2-phenylindole dihydrochloride (DAPI) (Merck KGaA, Darmstadt, Germany). During IMS, the dissociation procedure to separate the oocysts from the beads was repeated during the first two sampling rounds but was reduced to once as the procedure was lengthy and not fruitful for improved oocyst recovery in test and validation samples (data not shown). The analytical procedure was validated in-house by seeding four $10 \mathrm{~L}$ samples of swimming pool water from each of two pools (one chlorinated and one brominated) with 99 pre-stained Cryptosporidium oocysts (ColorSeed ${ }^{\mathrm{TM}}$, TCS Biosciences, Botolph Claydon, UK) and recording oocyst counts following the first and second dissociation steps.

Cryptosporidium oocysts in backwash samples were enumerated following centrifugation and IFM: the $1 \mathrm{~L}$ samples were split between two $500 \mathrm{~mL}$ bottles and centrifuged at $1140 \pm 20 \times g$ for $15 \pm 2 \mathrm{~min}$, the supernatant removed by aspiration and the pellet re-suspended in $500 \mathrm{~mL}$ reverse osmosis $(\mathrm{RO})$ water and the process repeated until the supernatant was clear. The final pellet was re-suspended in $25 \mathrm{~mL} \mathrm{RO}$ water and transferred to a $50 \mathrm{~mL}$ conical centrifuge tube. A further $20 \mathrm{~mL}$ RO water was used to rinse the $500 \mathrm{~mL}$ bottle and added to the $50 \mathrm{~mL}$ tube. The suspension was vortex mixed for $20 \mathrm{~s}$ and allowed to stand at room temperature for $20 \mathrm{~min}$, so that fibrous material settled to the bottom of the tube. The supernatant was removed with a pipette and transferred to a clean $50 \mathrm{~mL}$ centrifuge tube and centrifuged at $1140 \pm 20 \times \mathrm{g}$ for $15 \mathrm{~min}$, and the pellet volume recorded. The supernatant was removed by the aspiration to within $5 \mathrm{~mL}$ of the pellet and $\mathrm{RO}$ water added to the $7.5 \mathrm{~mL}$ mark on the tube. The pellet was re-suspended by vortex mixing for $20 \mathrm{~s}$ and transferred using a pipette to measure the volume into a Leighton tube. Sufficient $\mathrm{RO}$ water was added to the centrifuge tube and vortex mixed to rinse for $20 \mathrm{~s}$ and transferred to the Leighton tube so that the final volume was $10 \mathrm{~mL}$. The sample was stored at $5^{\circ} \mathrm{C}$ until processing in its entirety by IMS, and the oocysts stained and enumerated as described above. Oocyst recoveries were monitored by spiking each $1 \mathrm{~L}$ sample with 99 pre-stained oocysts (ColorSeed ${ }^{\mathrm{TM}}$, TCS Biosciences, Biddulph Clayton, UK) according to the manufacturer's instructions.

Cryptosporidium oocyst counts were reported to the project manager within 1 week of sample receipt and positive results discussed with the pool operators, management and local environmental health and health protection teams, in the context of the pool's management, construction and operational performance.

\subsection{Detection of Bacterial Indicator Organisms in Pool Water}

Colony counts were used to enumerate colony forming units $(\mathrm{cfu}) / \mathrm{mL}$ after incubation at $37{ }^{\circ} \mathrm{C}$ for $24 \mathrm{~h}$ for aerobic bacteria, and estimate the most probable number (MPN)/100 mL for total coliforms, Escherichia coli, and Pseudomonas aeruginosa in pool water samples (Latis Scientific, Crayford, London, UK) using standard methods [28]. Results were reported to pool operators directly, and to the project manager, within $72 \mathrm{~h}$ of receipt. 


\subsection{Statistical Analyses}

Data and results were collected weekly and tabulated in an Excel spreadsheet (Supplementary Materials Table S1). Occurrence and average concentration of oocysts per $10 \mathrm{~L}$ pool water and per $1 \mathrm{~L}$ backwash on the sampling days were compared. Unadjusted and adjusted counts (taking into account oocyst recovery data, and results from the first dissociation only) were used. Bacterial indicator results were classified as satisfactory or unsatisfactory [30]. The associations between oocyst detection and measured parameters were investigated for dichotomous outcome variables using Chi-squared/Fisher's exact test and for continuous outcome variables using t-test or Mann-Whitney $U$ test. Sample volumes and oocyst counts were compared using Spearman's rank correlation coefficient. Median oocyst recovery rates from chlorinated and brominated pools were compared using the Mann-Whitney U test, and from backwash samples from three pools using the KruskalWallis test. Differences with $p$-values of $<0.05$ were considered statistically significant.

\subsection{Probabilistic Modelling of Cryptosporidium Contamination Events}

These data were used to enable probabilistic modelling of the likelihood of there being a measurable input of oocysts into the pool during the course of a day, and whether any such inputs were likely to be single or multiple events. The likelihood of an 'oocyst event' during the course of a day was based on the notion of a 1 in $\mathrm{N}$ chance of a bather contaminating the pool with a measurable quantity of oocysts. If so, the fraction (f) of days when there was likely to be a detectable contamination event was given by Equation (1):

$$
f=1-\left(\left(1-\frac{1}{N}\right)^{n}\right)
$$

where $n$ was the number of bathers using the pool that day. The greater the daily bather number, the more frequent will be days with detectable oocyst contamination. As the pools varied widely in daily bather number, this was likely to be an important factor contributing to any observed differences between pools in oocyst detection frequency.

To address the question "when oocysts were detected, what is the likelihood that the contamination was from a single bather or multiple bathers?", a Monte Carlo simulation was undertaken. To simulate whether the next bather to enter the pool was a 'contaminator', a random integer was selected between 1 and $N$. If 'number two' was selected, that designated the bather as being a contaminator. Repeating this selection process $n$ times (where $\mathrm{n}$ was the number of bathers entering the pool that day) provided a value for the number of 'number two' events recorded for this trial. For a given combination of $N$ and $n$, the trial was repeated 1000 times, from which the likely fraction of days with $0,1,2,3$ etc. events could be estimated. The fraction of days where the Monte Carlo simulation predicted any contamination should agree with the prediction of Equation (1).

\section{Results}

\subsection{Oocyst Detection, Bacterial Indicator Organisms and Physical-Chemical Properties}

The recorded pool operating parameters and the results of testing for bacteriological indicator organisms (Table 3) were mostly compliant with the Pool Water Treatment Advisory Group (PWTAG) standards [30]. The MPN/100 mL was zero in all samples tested for total coliforms, Escherichia coli and Pseudomonas aeruginosa. Although aerobic colony counts were unsatisfactory ( $>100 \mathrm{cfu} / \mathrm{mL}$ ) in $12 / 57(21 \%)$ samples, none were consecutive samples (Table 3).

A total of 59 pool water samples were tested for Cryptosporidium over the ten week period (Table 3). Sample volumes ranged from 60 to $999 \mathrm{~L}$, median $493 \mathrm{~L}$, and were taken over 8 to $24 \mathrm{~h}$ periods, as the Filta-Max xpress ${ }^{\mathrm{TM}}$ filters sometimes became blocked, even when turbidity was within acceptable limits (Table 3).

Cryptosporidium oocysts were detected in 12/59 (20\%) samples. All detections were from the material obtained in the first IMS dissociation. Every pool had at least one 
positive pool water sample and up to four (Table 3). Most detections $(8 / 12,66 \%)$ were in August (weeks 1 to 4 ) when the number of people using the pools was highest (Table 4, Figure 1), and were significantly more likely to be positive than those taken after August (Fisher's exact 2 tailed test $p=0.045$ ). There was no statistically significant relationship between Cryptosporidium detections and any aerobic colony count (ACC) failures or other measured parameters.

Oocyst counts in pool water ranged from 0 to 1.16 oocysts per $10 \mathrm{~L}$ (mean 0.04 oocysts per $10 \mathrm{~L}$; median 0 ). Although the sample volumes varied, there was no significant difference between the volume of samples in which oocysts were detected (mean $415.9 \mathrm{~L}$, range 60-999.3 L) compared to those in which they were not (mean 530.9 L, range 181.3-992.1 L) ( $\mathrm{t}$-value 1.515, $p=0.135)$. There was no correlation between sample volume and oocyst counts (Spearman's rank correlation coefficient $0.071,95 \%$ CI $=-0.524-0.620$. In spiking experiments, there was no significant difference in the median oocyst recovery percentages from chlorinated pool water (58.1\%, range $46.5 \%$ to $61.6 \%$ ) and brominated pool water $(54.0 \%$, range $50.5 \%$ to $55.6 \%$ ) ( $p=0.31$ ). No environmental oocysts (not derived from spiking) were detected in these experimental samples. Environmental oocyst counts from weekly sampling were adjusted using the appropriate median recovery rate, and ranged from 0 to 2.11 oocysts, mean 0.08 , per $10 \mathrm{~L}$ pool water (Table 4). These data are for pools that differed in size and bather numbers and it is reasonable to assume there was a strong dependency between oocyst counts and (a) the number of bathers and (b) the volume of the pool. Other factors aside, the oocyst count would be proportional to the number of bathers and inversely proportional to the pool volume. In which case, data from pools with different volumes and bather numbers can be compared by multiplying the oocyst concentration by the pool volume and dividing by the bather number. This gives, in effect, the average number of residual oocysts per bather (Table 4), which ranged from 1.7 to 64.1 (mean 15.9, median 8.1).

Filter backwash was sampled from pools D, E and F (Tables 3 and 4). Environmental oocysts were detected in $2 / 28(7 \%)$ samples from pools $\mathrm{E}$ and F. One sample, at pool F, count of 4 oocysts $/ \mathrm{L}$, was taken on the day 1.16 oocysts $/ 10 \mathrm{~L}$ were detected in the pool water, which was the highest oocyst pool water count recorded for that site. The other detection in backwash was at pool E, where 1 oocyst/L was recorded on the day $0.04 / 10 \mathrm{~L}$ were detected in the pool water.

The median spike recovery for backwash recorded for samples from pool D was $54.1 \%$ (range $48.5 \%$ to $74.7 \%$ ), pool E was $55.6 \%$ (range $10.1 \%$ to $82.8 \%$ ) and pool $\mathrm{F}$ was $56.1 \%$ (range $20.2 \%$ to $74.7 \%$ ). Although the variance within the three sets of spike recovery data differed (Bartlett's Chi-square 9.26, $\mathrm{df}=2, p=0.01$ ), there was no significant difference in the median values (Kruskal-Wallis $\mathrm{H}=0.06, \mathrm{df}=2, p=0.97$ ). The adjusted environmental oocyst counts in the backwash were 2 and 8 oocysts/L.

Fourteen faecal accidents were reported over the 10 week period (Table 3), at least one and up to four per pool (Table 4). Two were liquid, at the same pool. Recorded actions were PWTAG compliant. One report was in the week preceding oocyst detection in the pool water sample (Table 4). 


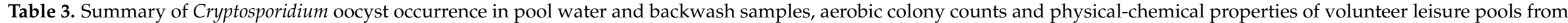
weekly sampling over 10 weeks from 8 August 2017.

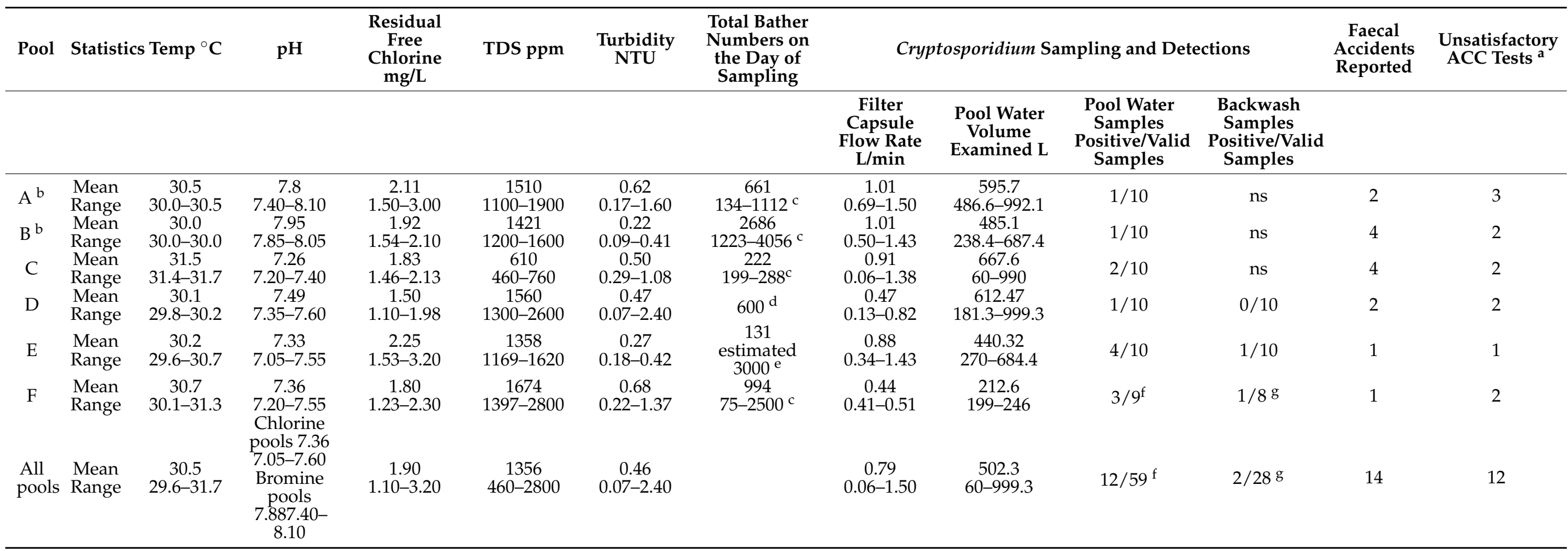

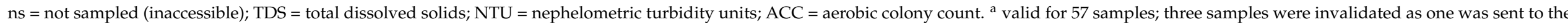

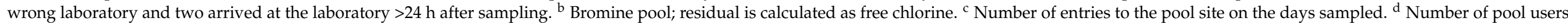

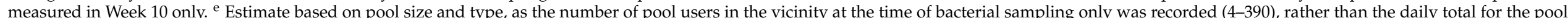

${ }^{\mathrm{f}}$ One sample was invalidated as it was sent to the wrong laboratory. ${ }^{\mathrm{g}}$ Two samples were invalidated; one because it was sent to the wrong laboratory, and the other because the spike recovery was zero. 
Table 4. Cryptosporidium oocyst detections and counts in pool water and backwash samples over 10 weeks from 8 August 2017.

\begin{tabular}{|c|c|c|c|c|c|c|c|c|c|c|c|}
\hline Week & Pool & $\begin{array}{c}\text { Bather Numbers } \\
\text { on Day of } \\
\text { Sampling }\end{array}$ & $\begin{array}{c}\text { Duration of Pool } \\
\text { Water Sampling for } \\
\text { Cryptosporidium min }\end{array}$ & $\begin{array}{c}\text { Pool } \\
\text { Water } \\
\text { OP } 10 \mathrm{~L}\end{array}$ & $\begin{array}{l}\text { Pool Water } \\
\text { OP } 10 \mathrm{~L} \\
\text { adj }\end{array}$ & $\begin{array}{c}\text { Calculated } \\
\text { Number of } \\
\text { Residual Oocysts/Bather }\end{array}$ & $\begin{array}{l}\text { Backwash } \\
\text { OP L }\end{array}$ & $\begin{array}{l}\text { TDS } \\
\text { ppm }\end{array}$ & $\begin{array}{c}\text { Turbidity } \\
\text { NTU }\end{array}$ & $\begin{array}{l}\text { Unsatisfactory } \\
\text { Aerobic Colony } \\
\text { Count }\end{array}$ & $\begin{array}{l}\text { Recorded } \\
\text { Faecal } \\
\text { Accidents }\end{array}$ \\
\hline 1 & A & 977 & 540 & 0.07 & 0.13 & 4.8 & ns & 1600 & 0.39 & No & No \\
\hline 2 & $\mathrm{C}$ & 288 & 960 & 0.17 & 0.30 & 9.0 & ns & 760 & 0.3 & No & No \\
\hline 2 & $\mathrm{E}$ & $3000^{c}$ & 478 & 0.09 & 0.16 & $7.1^{\mathrm{c}}$ & $<\mathrm{LOD}$ & 1252 & 0.3 & No & No \\
\hline 3 & B & 3797 & 480 & 0.32 & 0.58 & 22.9 & ns & 1600 & 0.19 & Yes & No \\
\hline 3 & $\mathrm{E}$ & $3000^{c}$ & 485 & 0.04 & 0.07 & $3.1^{c}$ & $<$ LOD & 1340 & 0.39 & No & No \\
\hline 4 & $\mathrm{E}$ & $3000^{c}$ & 490 & 0.04 & 0.08 & $3.5^{c}$ & 1 & 1340 & 0.21 & No & No \\
\hline 6 & $\mathrm{~F}$ & 200 & 480 & 0.05 & 0.09 & 13.5 & $<\mathrm{LOD}$ & 1515 & 0.89 & Yes & Yes \\
\hline 10 & $\mathrm{D}$ & 600 & $1440^{\mathrm{b}}$ & $0.01^{b}$ & 0.02 & 1.7 & $<\mathrm{LOD}$ & 1300 & 0.24 & No & No \\
\hline 10 & $\mathrm{~F}$ & 140 & 480 & 0.17 & 0.30 & 64.1 & $<$ LOD & 1397 & 0.22 & No & No \\
\hline 10 & $\mathrm{E}$ & $3000^{c}$ & 485 & 0.03 & 0.06 & $2.7^{c}$ & $<$ LOD & 1620 & 0.36 & No & No \\
\hline
\end{tabular}

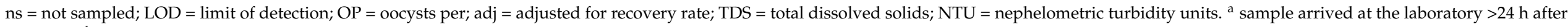
sampling. ${ }^{b}$ prolonged duration of sampling after the pool closed influenced oocyst concentration. ${ }^{c}$ estimated as actual total numbers of bathers were not available. 


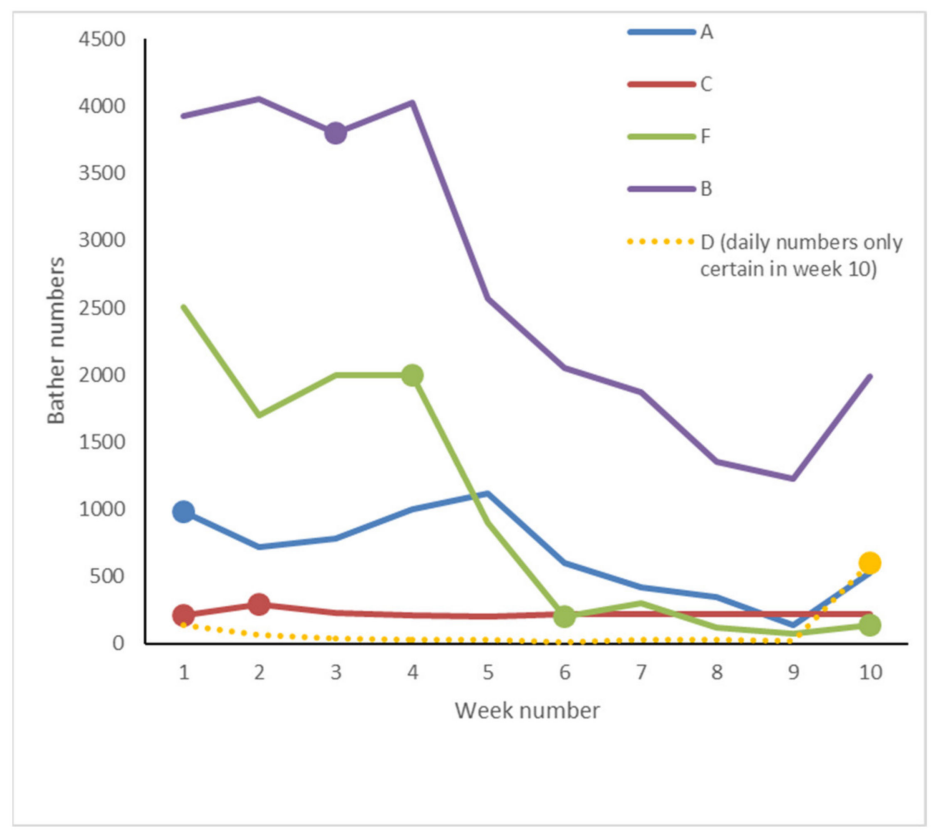

Figure 1. Daily bather numbers and Cryptosporidium detections (represented by circles) at five pools (A, B , C , D and F) provided the total bather number for the day of sampling. School holidays likely influenced bather numbers at most pools. Pool D was in Scotland where only sampling weeks 1 and 2 were in the summer holidays and week 10 was in the October holiday. For all other pools sampling weeks 1 to 5 were in the summer holidays.

\subsection{Oocyst Modelling}

Bather numbers for each of the sampling days were provided by four pools (A, B, C, and $\mathrm{F}$ ), one pool (D) provided an accurate daily bather number on just one of the sampling days, and one site (E) was unable to provide relevant all-day numbers (Table 4; Figure 1). This provided 41 days when valid Cryptosporidium results and daily bather numbers were recorded, with oocysts detected on eight of those sampling days (Figure 1). To investigate further the possible impact of daily bather number on the likelihood of there being recorded oocyst contamination, the data were grouped into two categories, $\leq 1000$ and $>1000$ daily bathers (Figure 1; Table 5).

Table 5. Observed frequency of Cryptosporidium oocyst detection grouped by nominal classes of recorded bather numbers at five pools.

\begin{tabular}{|c|c|c|c|c|c|}
\hline Class & $\begin{array}{l}\text { Daily Bather } \\
\text { Numbers }\end{array}$ & Pool & $\begin{array}{l}\text { No. Sample } \\
\text { Days }\end{array}$ & $\begin{array}{l}\text { No. Positive } \\
\text { Sample Days }\end{array}$ & $\begin{array}{c}\% \text { Positive } \\
\text { Sample Days }\end{array}$ \\
\hline \multirow[t]{5}{*}{1} & 0-1000 & A & 9 & 1 & \\
\hline & mean $=387$ & C & 10 & 2 & \\
\hline & & D & 1 & 1 & \\
\hline & & $\mathrm{F}$ & 6 & 2 & \\
\hline & & Total & 26 & 6 & 23.1 \\
\hline \multirow[t]{4}{*}{2} & $1001-4069$ & A & 1 & 0 & \\
\hline & mean $=2411$ & B & 10 & 1 & \\
\hline & & $\mathrm{F}$ & 4 & 1 & \\
\hline & & Total & 15 & 2 & 13.3 \\
\hline 1 and 2 & $\begin{array}{c}0-4069 \\
\text { mean }=1127\end{array}$ & TOTAL & 41 & 8 & 19.5 \\
\hline
\end{tabular}

Figure 2 shows the overall fraction of days with oocyst detections plotted against the mean (nominal) bather number for the class (from Table 5), and the relationship predicted by Eqn 1 between the fraction of 'positive' days as a function of daily bather number based 
on variable probabilities of a bather being a contaminator ranging from 1 in 1000 to 1 in 10,000 . The average pool volumes (weighted by the number of days each pool contributed) contributing to the data in classes 1 and 2 in Table 5 were 245 and $1101 \mathrm{~m}^{3}$ respectively. Smaller pools in class 1 appeared to have a frequency of detectable 'oocyst event days' consistent with there being much greater odds of a bather being a contaminator than larger pools in class 2; much greater numbers of samples would be required to provide a more confident assessment.

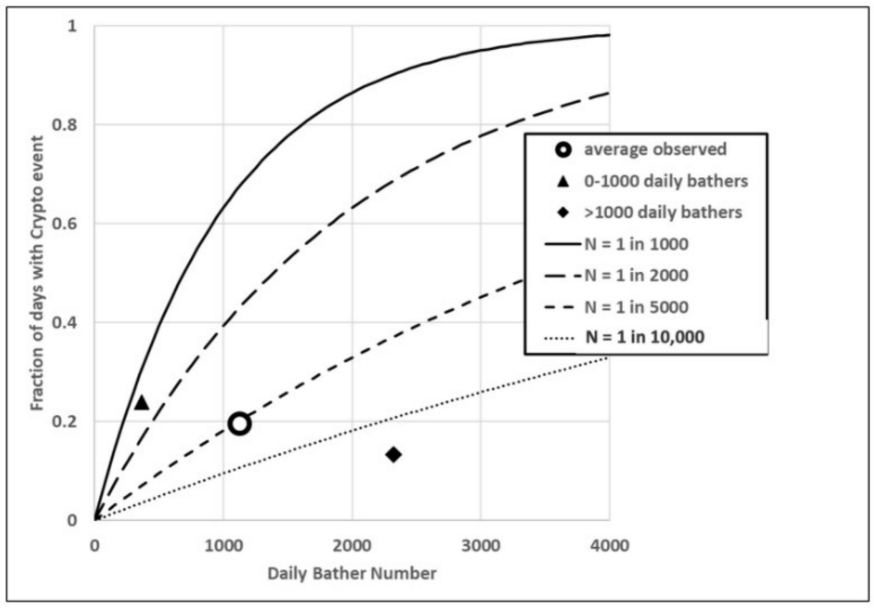

Figure 2. The impact of daily bather number (n) and the probability of a bather being an oocyst shedder ( $N=1$ in 1000, 1 in 2000, 1 in 5000 or 1 in 10,000) on the fraction of days with detectable Cryptosporidium contamination. Lines show predicted results using Equation (1) and symbols show the observed results.

Pooling the data gave $19.5 \%$ of days with Cryptosporidium detections, with an average of 1127 bathers per day (Table 5). This corresponded to an average probability of about 1 in 5000 of a bather shedding sufficient oocysts to provide a detectable number in the pool. This probability affected not only the chance of there being oocyst contamination on a given day but also the likely number of contamination events within a day. The results of the Monte Carlo simulation (Figure 3) show the expected frequency of multiple event days for different combinations of oocyst shedder probability and bather number. If there were sufficient bathers (daily bather number) to predict that more than $70 \%$ of days had measurable oocyst contamination, then the probability of multiple events exceeded that of there being just a single event. For example, 3000 daily bathers with a 1 in 2000 probability of a bather being an oocyst shedder were expected to give $79 \%$ of days with measurable contamination, comprising $46 \%$ of days with multiple events and $33 \%$ with a single event (Figure 3).

We now turn attention to how the average concentration of oocysts measured over a day in this study could relate to the peak concentration that occurred at the time of a single contamination event. In a well-mixed pool, the removal of particles or turbidity by filtration is expected to reduce the residual concentration in the pool exponentially, where the rate of decline depends on the turnover time and the filter removal efficiency. With effective filtration, the removal efficiency for Cryptosporidium oocysts is assumed to be at least $90 \%$ [12]. If so, then as a first approximation, it is expected that $57 \%$ of any oocysts present at the start of each turnover will be removed during the course of the turnover [12]. The solid line in Figure 4 shows the expected decline in numbers for such a case following a contamination event. The dashed line shows the approximate mean concentrations of oocysts present during each of the 4 turnovers following the contamination event $(72 \%$, $30 \%, 13 \%$ and $6 \%$ of the initial concentration respectively). 


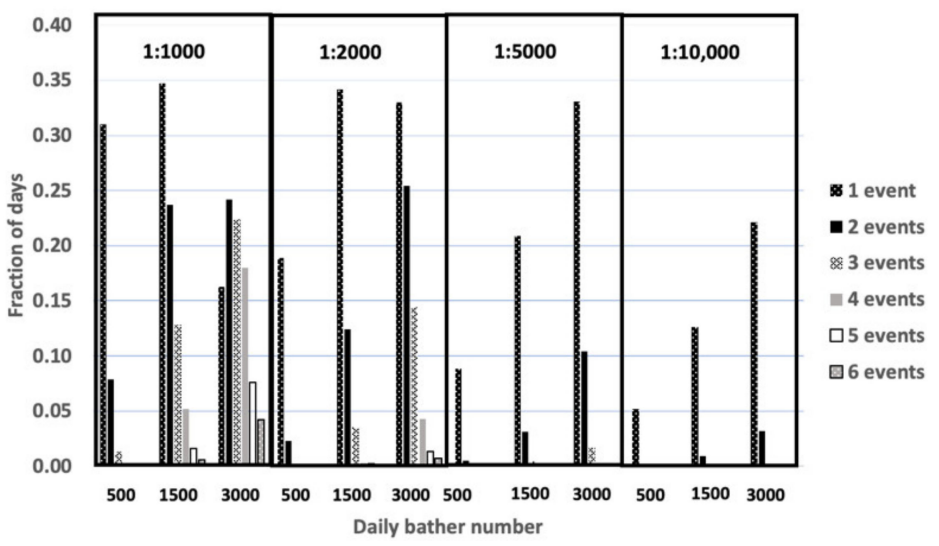

Figure 3. Monte Carlo analysis of the predicted impact of daily bather number ( $\mathrm{n}=500,1500$ or 3000 ) and the probability of a bather shedding a detectable number of oocysts $(\mathrm{N}=1$ in 1000, 1 in 2000, 1 in 5000 or 1 in 10,000) on the number of Cryptosporidium contamination events expected in a single day (expressed as the fraction of days predicted to have one to six events).

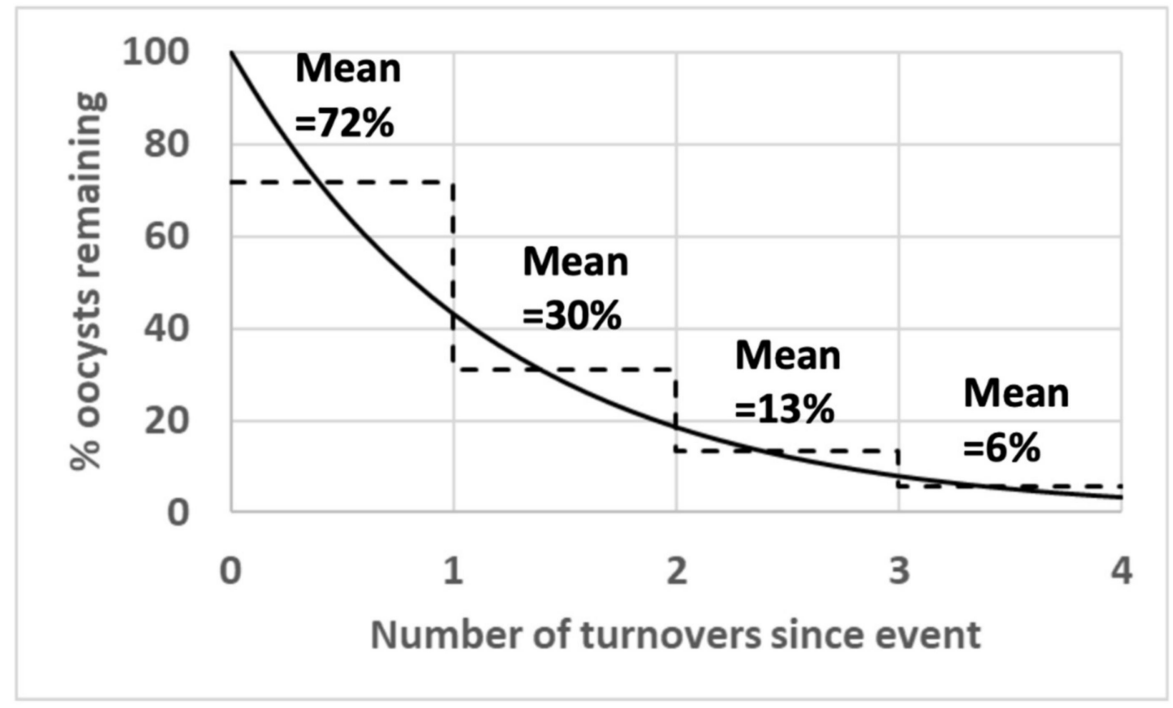

Figure 4. The decline in the concentration of oocysts for a pool where $57 \%$ of particles present at the start of each turnover are removed during the course of the turnover period. The histograms show the approximate average percentage of the initial concentration of oocysts expected to be present in the pool throughout each successive turnover period following the contamination event.

In Table 6 these values were used to compute the average expected concentration (as a percentage of the peak) during the course of the day, depending on just when the contamination occurred. The highest concentration of oocysts recorded was 2.11 per $10 \mathrm{~L}$ (pool F, week 4) when water was sampled from 08:00 to 16:00 $\mathrm{h}$ (Table 4). The turnover time for this pool was within a few minutes of $2 \mathrm{~h}$ (Table 2). Table 6 shows, for different presumed times of contamination, the effect of successive 2-h turnovers on the oocyst concentrations in terms of the percentage of the peak value. If the contamination event occurred between 08:00 and 14:00 $\mathrm{h}$, then the measured average concentration over the 8-h sampling period was predicted to be between $31 \%$ and $18 \%$ of the peak concentration. On this basis we can be reasonably confident that the peak concentration was likely to have been no greater than 5 times the average value measured over the day (i.e., 10.5 oocysts per $10 \mathrm{~L}$ in this case of the highest concentration we detected), provided the event was more than one turnover before the end of the sampling period (but could be greater if the event occurred much closer to the end of the sampling period). 
Table 6. Average expected concentration of oocysts (expressed as a percentage of the initial peak) during each successive turnover period during the course of a day, depending on just when the contamination occurred, for a pool with a two hour turnover period.

\begin{tabular}{|c|c|c|c|c|c|}
\hline \multirow[b]{2}{*}{$\begin{array}{c}\text { Oocyst Contamination } \\
\text { Time (h) }\end{array}$} & \multicolumn{4}{|c|}{ Turnover Period (h) } & \multirow[b]{2}{*}{$\begin{array}{l}\text { 08:00-16:00 } \\
\text { Mean }\end{array}$} \\
\hline & 08:00-10:00 & 10:00-12:00 & 12:00-14:00 & 14:00-16:00 & \\
\hline 08:00 & 72 & 30 & 13 & 6 & 30 \\
\hline $10: 00$ & 0 & 72 & 30 & 13 & 29 \\
\hline $12: 00$ & 0 & 0 & 72 & 30 & 26 \\
\hline $14: 00$ & 0 & 0 & 0 & 72 & 18 \\
\hline
\end{tabular}

\section{Discussion}

During the summer and early autumn of 2017, pool water samples and operational data were collected from six volunteer leisure pools, and filter backwash samples were collected from three. The results of testing for bacterial indicator organisms and physicalchemical properties indicated that the disinfection at the pools was well managed, but that the Cryptosporidium was present in $20 \%$ pool water samples and $7 \%$ backwash water samples, the latter following detections in pool water. Simultaneous sampling for faecal indicator organisms, $\mathrm{pH}$, residual free chlorine, combined chlorine, and turbidity indicated the pool water treatment performance was good. Even so, a risk of Cryptosporidium transmission posed by the contamination of pools was identified, although no outbreaks were associated with the pools during the survey. The oocyst detections in filter backwash coincided with peak detections in pool water, and the number of oocysts detected was higher in filter backwash than in the pool water, demonstrating the role of effective filtration in removing oocysts, and re-enforces PWTAG guidance to mitigate that risk [30]. Previous surveys in other countries have reported Cryptosporidium in swimming pool waters and filter backwash in widely varying numbers/frequencies using a variety of sampling regimes and test methods (Table 1). Although many of those pools returned unsatisfactory water quality test results, few statistically significant associations with Cryptosporidium detection were identified. Although such indicators are not informative for the presence of this parasite, they are indicative of the management and control of the disinfection system [7]. One study in China reported a strong correlation between parasite (Cryptosporidium and Giardia) detection and urea in pool water [11]; urea can be an indicator of bather pollution [31] but is not a routine test parameter in the UK. In our study, where bacterial indicator results indicated pool water disinfection was generally well managed, oocyst detections were correlated with peak periods in terms of bather numbers which provides operators with an easily implementable control point. Bather numbers were reported in six of the 16 papers summarised in Table $1[16,18-21,27]$ but were not analysed statistically with Cryptosporidium detections. In one study, oocysts were not detected in pools with fewer users ( $<100 /$ day), whereas pools with a medium user frequency (100-500/day) had the highest oocyst prevalence (25\%) [27].

This study provided, for the first time, validation data for testing swimming pool water and backwash for Cryptosporidium. The $54.8 \%$ mean oocyst recovery in validation spiking trials for swimming pool waters was well within the acceptable range for drinking water [32], indicating that standard methods for drinking water are applicable to pool waters. The numbers of oocysts detected were within the ranges reported previously for swimming pools (Table 1) but here we were able to adjust the counts for recovery rates, accommodating in part for the underestimation of oocyst numbers generated by test processes [32].

During our survey, it was notable that no oocysts were detected on $33(80 \%)$ of the 41 days of sampling in the 5 pools where daily bather numbers were recorded, despite over 38,000 bathers using the pools on those days. This implies that (a) there was no long-term (i.e., multi-day) residual presence of oocysts in the pool water following a contamination event and (b) the large majority of bathers were not oocyst shedders. We shall discuss 
each in turn and have assumed the sole source of oocysts to be bathers (based on the transmission pathway of [33] not a contaminated water supply. The water providers assured us there were no oocyst detections in the supplies during the sampling period, the pools were operated to high standards and there was no evidence of cross-connections, and any outdoor areas were protected to prevent the entry of animals to the pools. Therefore the Cryptosporidium-positive microscopy slides were not subjected to genotyping (which is challenging when small numbers of oocysts are present) to identify the species. Oocyst viability was not tested as there is no standardised or validated test for meaningful results from low numbers, and it is not unreasonable to assume that oocysts captured in pool water in a weekly monitoring regime are viable as they were likely to have been recently shed.

All the samples were taken at seven-day intervals, so there were no sequential days of oocyst monitoring to demonstrate a lack of carry-over from the data we collected. However, significant carry-over was not expected based on information about the removal of oocysts by filtration and the performance of the pool water treatment at the pools. For example, the basis of the UK guidelines for managing diarrhoea incidents is that with effective filtration $99.3 \%$ of oocysts are expected to be removed from pool water during six turnovers of circulation [30]. Even if filters are achieving only 50\% removal of oocyst-sized particles, the percentage of oocysts removed after six turnovers is still expected to be $90 \%$ [12]. The pools studied had turnover times ranging from 1.5 to $2.75 \mathrm{~h}$, so would have achieved at least five turnovers overnight when there were no bathers present. This indicates that even with a relatively poor filtration efficiency of $50 \%$, at least $85 \%$ of oocysts would have been removed from the pool even if a contamination event occurred just at the time of closure. Therefore, it is reasonable to assume that if measurable numbers of oocysts were recorded on a given day, then the contamination event(s) responsible were highly likely to have occurred that day.

Although the number of samples was limited, the implications of there being relatively few oocyst detection days was that the probability of a bather being a shedder of a detectable number of oocysts fell within the range of 1 in 1000 to 1 in 10,000 or lower, the average being around 1 in 5000. Therefore it would be expected that most days would not see a detectable oocyst contamination event. A number of demographic, risk factor, environmental and socioeconomic factors affect whether someone is infected with Cryptosporidium, and sheds oocysts, and is likely to contaminate a pool including age, sex, location, season and bather type. For example, one study in the UK of young children reported a point prevalence carriage rate of $1.3 \%$ (95\% confidence interval: $0.3-3.8 \%$ ) [34]. However, we had insufficient data from this study for multifactorial analysis.

The data for predicted 'oocyst contamination days' shown by the lines in Figure 3 suggest that the range of daily bather numbers reported in this study is within that where the fraction of days where oocysts expected to be recovered is sensitive to daily bather number. This explains why there was a statistically significant greater fraction of 'oocyst contamination' days in August (when bather numbers were greatest) than after August.

The Monte Carlo simulations indicated that multiple contamination events (associated with multiple bathers) were predicted to be most likely when there were more than $70 \%$ of days with contamination. When contamination days were less frequent than any oocyst contamination was most likely to be associated with a single bather.

The discussion so far has centred around whether or not there has been contamination on a given day, and the factors affecting the frequency of such days. We now discuss preliminary indications for the possible magnitude of contamination and peak concentration on these days, and the implications for the risk of ingestion of oocysts by other bathers. The only information we have that is indicative of the magnitude of the contamination of the pool water is the average concentration recorded over a period of continuous sampling from before the pool opened to after it closed. The data shown in Table 6 indicate that, as a first approximation, the maximum peak concentration was likely to have been in the order of 10 oocysts per $10 \mathrm{~L}$ (i.e., approximately 5 times the detected concentration averaged over $8 \mathrm{~h}$ of sampling). If the average ingestion of water by an adult bather is $37 \mathrm{~mL}$ [35], then 
this would imply a 1 in 27 chance of an adult ingesting a single oocyst at the time of peak concentration. Given this, the importance of secondary disinfection is recommended for such pools is clear $[30,36]$.

It is also notable that it was one of the smaller pools that had the highest oocyst concentration averaged over the sample period. It would be expected that for a given magnitude of event (in terms of numbers of oocysts contaminating the pool) a higher concentration would be found in a smaller pool with less water volume. The increased dilution of oocyst concentrations in a larger pool might have contributed to the observation that it was the smaller pools that seemed to have the higher probability of a bather being a detectable oocyst shedder. For example, at pool C which had a volume of $86 \mathrm{~m}^{3}$ one of the recorded oocyst concentrations was 0.3 per $10 \mathrm{~L}$. Had the same event occurred at pool B then the extra dilution in this $1500 \mathrm{~m}^{3}$ pool (assuming perfect mixing) would have reduced the concentration to 0.017 per $10 \mathrm{~L}$ which might not have been detected. The normalising of oocyst counts to give the number of residual oocysts per bather (Table 4) provides a means of using these data in future work on QMRA, enabling generalizable models.

A final point to note from this analysis was that if the peak concentration (estimated for pool F, week 4) was 10 oocysts per $10 \mathrm{~L}$, then multiplying by the volume of the pool $\left(299 \mathrm{~m}^{3}\right)$ and assuming the sampling captured all the oocysts, suggests a total input of around 30,000 oocysts. This number is several orders of magnitude smaller than the $10^{8}-10^{9}$ oocysts expected from an acute cryptosporidiosis-related diarrhoea event [6] but is within the range expected from asymptomatic individuals [37] assuming a stool mass of $123.6 \mathrm{~g}$ [38]. Similar analysis of the four highest concentrations of oocysts recovered in this study suggested total numbers of oocysts in the range $10^{4}-10^{5}$.

Information collected about reported faecal accidents in this study indicates most were of solid stools and were observed between once and four times, similar to [15] who also found no temporal relationship with positive protozoa findings. Aside from the fact that liquid stools may not be observed and reported, oocyst inputs in this range may well come from asymptomatic infections, recuperating patients and/or simply dirty bottoms. For example, the concentration of Cryptosporidium hominis oocysts detected in stools from young children without diarrhoea in a carriage study in the UK was $1.3 \times 10^{4}$ oocysts per gram [34]. This re-enforces the importance of reporting and dealing with faecal accidents, promoting bather hygiene, and excluding recuperating patients from swimming for two weeks after symptoms have ceased.

The timing of the oocyst contamination in relation to the sampling period was also an important factor. The difference between contamination occurring at the start of the day compared to occurring after 3 turnover periods have elapsed is likely to reduce the mean concentration of oocysts detected two-fold. If the study aimed to estimate the total number of oocysts added to the pool, then sampling could be improved by allowing the sampling period to extend for at least two turnover periods following the last possible opportunity for a contamination event i.e., for two turnovers following closing the pool at the end of the day. However, the practicalities of this would need to be considered in the provision of labour to remove sample filters as well as the timing of filter backwashing and backwash sampling. However, if the study aimed to survey the concentration of oocysts bathers are exposed to (e.g., to validate a QMRA), then the sampling period should ideally only cover the period bathers are in the pool. In this study, most sampling periods finished soon after the pool closed whereas at one pool (D) filters were left overnight, in which case there would substantial dilution of the oocyst concentration in the sampled volume because there had been at least 5 turnovers after the pool was closed, which would be expected to remove well over $95 \%$ of the oocysts in the water. However, this did not affect the results based on oocyst detections. Though beyond the scope of this paper, future studies of this sort should incorporate a method for estimating the average concentration during the period bathers are in the pool from recovered concentrations over more extended sampling periods.

These preliminary estimates are based on the assumption that pools are perfectly mixed. This may be a reasonable assumption after several turnovers during which oocysts 
are transported to the filtration system [39], and especially in this study where there was additional forced mixing due to the presence of pumped water features. However, there will not be a uniform distribution of oocysts in the minutes following localised oocyst contamination. Swimmers in the immediate vicinity at the time would be very likely to ingest oocysts, so the probability of the number of contamination events provides a better indicator of risk. Secondary disinfection such as UV is also unlikely to play a role immediately following a contamination event because this requires time for the circulation of water from the pool to the plant room.

This study has generated quantitative data on the occurrence and concentration of Cryptosporidium oocysts in leisure pools in the UK, which will enable contextualisation of test results and provide data to contribute to QMRA of infection risk for the UK population. These data could be used, for example, to validate the approaches developed by Suppes and colleagues [8] and Falk and colleagues [40] to quantify the risk of illness associated with the introduction of Cryptosporidium oocysts into pool water by swimmers. Preliminary modelling of oocyst concentration and temporal inputs can be used to guide future studies, for which simultaneous measurements of the filter removal efficiency in the appropriate size range using particle counting would aid the interpretation and modelling of results [12]. An additional, practical benefit of this work is that improved sampling capacity is provided by the six sampling rigs constructed. The findings from this work provide an evidence-base for encouraging seasonal public awareness campaigns for bather hygiene and reminding pool operators of current standards and procedures for managing bather loads and faecal accidents.

\section{Conclusions}

We conclude that Cryptosporidium oocyst enumeration methods for drinking water are applicable for swimming pool water. Oocyst detections are not infrequent in leisure pools, especially during busy periods. Modelling indicated improvement for sampling regimes, and signalled towards oocyst contamination events, although larger studies need to be done. Implications are that public health messages on bather hygiene and guidance for pool operators should be timed ahead of peak season.

Supplementary Materials: The following are available online at https: / www.mdpi.com/article/ 10.3390/w13111503/s1; Figure S1 Standardised Form for data collection at the time of sampling; Table S1 Pool water sampling data.

Author Contributions: Conceptualization, R.M.C., L.P.S. and M.W.; methodology, all authors; validation, R.M.C. and M.L.; formal analysis, M.L. and R.M.; investigation, R.M.C., M.L., R.M. and R.J.; resources, R.M.C., M.L. and R.M.; data curation, R.M.C., L.P.S.; writing—original draft preparation, R.M.C.; writing—review and editing, all authors.; visualization, L.P.S.; supervision, R.M.C. and R.J.; project administration, R.M.C.; funding acquisition, R.M.C. All authors have read and agreed to the published version of the manuscript.

Funding: This research was funded by The Pool Water Treatment Advisory Group. The laboratory work was funded by TCS Biosciences, BTF, IDEXX and Latis Scientific, the sampling rigs and their installations were funded by Certikin, Howard Gosling and Total Pool Chemicals Ltd., and Tintometer Limited provided hand-held turbidity meters.

Institutional Review Board Statement: Not applicable.

Informed Consent Statement: Not applicable.

Data Availability Statement: Data was available in the supplemental materials.

Acknowledgments: We thank TCS Biosciences, BTF, IDEXX and Latis Scientific for providing laboratory reagents, Certikin, Howard Gosling and Total Pool Chemicals Ltd. for providing the sampling rigs and their installation, Tintometer Limited for providing hand-held turbidity meters, the Local Authorities for undertaking the initial pool check lists, and the management and operators at each pool for participating and taking the samples. 
Conflicts of Interest: The authors declare no conflict of interest. R.M.C., M.W., and R.J. are members of the PWTAG Council. PWTAG Council members advised on the practicalities of the pool recruitment and sampling but apart from those listed as authors had no role in the design of the study; in the collection, analyses, or interpretation of data; in the writing of the manuscript, or in the decision to publish the results.

\section{References}

1. Smith, A.; Reacher, M.; Smerdon, W.; Adak, G.K.; Nichols, G.; Chalmers, R.M. Outbreaks of waterborne infectious intestinal disease in England and Wales, 1992-2003. Epidemiol. Infect. 2006, 134, 1141-1149. [CrossRef]

2. Chalmers, R.M.; Robinson, G.; Elwin, K.; Elson, R. Analysis of the Cryptosporidium spp. and gp60 subtypes linked to human outbreaks of cryptosporidiosis in England and Wales, 2009 to 2017. Parasites Vectors 2019, 12, 95. [CrossRef]

3. Hlavsa, M.C.; Cikesh, B.L.; Roberts, V.A.; Kahler, A.M.; Vigar, M.; Hilborn, E.D.; Wade, T.J.; Roellig, D.M.; Murphy, J.L.; Xiao, L.; et al. Outbreaks associated with treated recreational water-United States, 2000-2014. MMWR 2018, 67, 547. [CrossRef]

4. Messner, M.J.; Chappell, C.L.; Okhuysen, P.C. Risk assessment for Cryptosporidium: A hierarchical Bayesian analysis of human dose response data. Water Res. 2001, 35, 3934-3940. [CrossRef]

5. Shields, J.M.; Hill, V.R.; Arrowood, M.J.; Beach, M.J. Inactivation of Cryptosporidium paroum under chlorinated recreational water conditions. J. Water Health 2008, 6, 513-520. [CrossRef] [PubMed]

6. Gregory, R. Bench-marking pool water treatment for coping with Cryptosporidium. J. Environ. Health Res. 2002, 1, 11-18.

7. Ryan, U.; Lawler, S.; Reid, S. Limiting swimming pool outbreaks of cryptosporidiosis-the roles of regulations, staff, patrons and research. J. Water Health 2017, 15, 1-16. [CrossRef] [PubMed]

8. Suppes, L.M.; Canales, R.A.; Gerba, C.P.; Reynolds, K.A. Cryptosporidium risk from swimming pool exposures. Int. J. Hyg. Environ. Health 2016, 219, 915-919. [CrossRef]

9. Pintar, K.D.M.; Fazil, A.; Pollari, F.; Charron, D.F.; Waltner-Toews, D.; McEwen, S.A. A risk assessment model to evaluate the role of fecal contamination in recreational water on the incidence of cryptosporidiosis at the community level in Ontario. Risk Anal. 2010, 30, 49-64. [CrossRef] [PubMed]

10. Petterson, S.R.; Signor, R.S.; Ashbolt, N.J. Incorporating method recovery uncertainties in stochastic estimates of raw water protozoan concentrations for QMRA. J. Water Health 2007, 5 (Suppl. S1), 51-65. [CrossRef]

11. Xiao, S.; Yin, P.; Zhang, Y.; Hu, S. Occurrence of Cryptosporidium and Giardia and the relationship between protozoa and water quality indicators in swimming pools. Korean J. Parasitol. 2017, 55, 129-135. [CrossRef] [PubMed]

12. Wood, M.; Simmonds, L.; MacAdam, J.; Hassard, F.; Jarvis, P.; Chalmers, R.M. Role of filtration in managing the risk from Cryptosporidium in commercial swimming pools-a review. J. Water Health 2019, 17, 357-370. [CrossRef] [PubMed]

13. Fournier, S.; Dubrou, S.; Liguory, O.; Gaussin, F.; Santillana-Hayat, M.; Sarfati, C.; Molina, J.M.; Derouin, F. Detection of microsporidia, cryptosporidia and giardia in swimming pools: A one-year prospective study. FEMS Immunol. Med. Microbiol. 2002, 33, 209-213. [CrossRef]

14. Karanis, P.; Papadopoulou, C.; Kimura, A.; Economou, E.; Kourenti, C.; Sakkas, H. Cryptosporidium and Giardia in natural, drinking, and recreational water of Northwestern Greece. Acta Hydrochim. Hydrobiol. 2002, 30, 49-58. [CrossRef]

15. Schets, F.M.; Engels, G.B.; Evers, E.G. Cryptosporidium and Giardia in swimming pools in the Netherlands. J. Water Health 2004, 2, 191-200. [CrossRef]

16. Bonadonna, L.; Briancesco, R.; Magini, V.; Orsini, M.; Romano-Spica, V. A preliminary investigation on the occurrence of protozoa in swimming pools in Italy. Ann. Ig. 2004, 16, 709-719. [PubMed]

17. Briancesco, R.; Bonadonna, L. An Italian study on Cryptosporidium and Giardia in wastewater, fresh water and treated water. Environ. Monit. Assess. 2005, 104, 445-457. [CrossRef]

18. Oliveri, R.; Di Piazza, F.; Marsala, B.; Cerame, G.; Firenze, A.; Di Benedetto, M.A. Occurrence of Giardia cysts and Cryptosporidium oocysts in swimming pools in the province of Palermo, Italy. Ann. Ig. 2006, 18, 367-374. [PubMed]

19. Papadopoulou, C.; Economou, V.; Sakkas, H.; Gousia, P.; Giannakopoulos, X.; Dontorou, C.; Filioussis, G.; Gessouli, H.; Karanis, P.; Leveidiotou, S. Microbiological quality of indoor and outdoor swimming pools in Greece: Investigation of the antibiotic resistance of the bacterial isolates. Int. J. Hyg. Environ. Health 2008, 211, 385-397. [CrossRef]

20. Shields, J.M.; Gleim, E.R.; Beach, M.J. Prevalence of Cryptosporidium spp. and Giardia intestinalis in swimming pools, Atlanta, Georgia. Emerg. Infect. Dis. 2008, 14, 948-950. [CrossRef]

21. Abd El-Salam, M.M. Assessment of water quality of some swimming pools: A case study in Alexandria, Egypt. Environ. Monit. Assess. 2012, 184, 7395-7406. [CrossRef] [PubMed]

22. Kumar, T.; Onichandran, S.; Lim, Y.A.; Sawangjaroen, N.; Ithoi, I.; Andiappan, H.; Salibay, C.C.; Dungca, J.Z.; Chye, T.T.; Sulaiman, W.Y.; et al. Comparative study on waterborne parasites between Malaysia and Thailand: A new insight. Am. J. Trop. Med. Hyg. 2014, 90, 682-689. [CrossRef]

23. Onichandran, S.; Kumar, T.; Salibay, C.C.; Dungca, J.Z.; Tabo, H.A.; Tabo, N.; Tan, T.C.; Lim, Y.A.; Sawangjaroen, N.; Phiriyasamith, S.; et al. Waterborne parasites: A current status from the Philippines. Parasites Vectors 2014, 7, 244. [CrossRef]

24. Ehsan, A.; Casaert, S.; Levecke, B.; Van Rooy, L.; Pelicaen, J.; Smis, A.; De Backer, J.; Vervaeke, B.; De Smedt, S.; Schoonbaert, F.; et al. Cryptosporidium and Giardia in recreational water in Belgium. J. Water Health 2015, 13, 870-878. [CrossRef] 
25. Murphy, J.L.; Hlavsa, M.C.; Carter, B.C.; Miller, C.; Jothikumar, N.; Gerth, T.R.; Beach, M.J.; Hill, V.R. Pool water quality and prevalence of microbes in filter backwash from metro-Atlanta swimming pools. J. Water Health 2018, 16, 87-92. [CrossRef]

26. Wei, X.; Li, J.; Hou, S.; Xu, C.; Zhang, H.; Atwill, E.R.; Li, X.; Yang, Z.; Chen, S. Assessment of microbiological safety of water in public swimming pools in Guangzhou, China. Int. J. Environ. Res. Public Health 2018, 15, 1416. [CrossRef]

27. Gracenea, M.; Castaño, S.; Méndez, J.; Lucena, F.; Gómez, M.S. Faecal contamination in public pools in Barcelona province: Cryptosporidium spp. and bacterial indicators. J. Water Health 2018, 16, 762-772. [CrossRef] [PubMed]

28. Standing Committee of Analysts-Methods for the Examination of Waters and Associated Materials. The Microbiology of Recreational and Environmental Waters Series. Available online: http:/ /www.standingcommitteeofanalysts.co.uk/ (accessed on 23 March 2021).

29. Standing Committee of Analysts—The Microbiology of Drinking Water (2010)—Part 14-Methods for the Isolation, Identification and Enumeration of Cryptosporidium Oocysts and Giardia Cysts. Available online: https://assets.publishing.service.gov.uk/ government/uploads/system/uploads/attachment_data/file/755552/Part_14-oct20-234.pdf (accessed on 23 March 2021).

30. Pool Water Treatment Advisory Group. Swimming Pool Water Treatment and Quality Standards for Pools and Spas, 3rd ed.; Pool Water Treatment Advisory Group: Chester, UK, 2017.

31. Khramov, V.A.; Gizzatova, G.L. Urea as an indicator of anthropogenic pollution of water of swimming pools. Gig. Sanit. 2006, 3, 3-4.

32. US Environmental Protection Agency. Method 1623.1: Cryptosporidium and Giardia in Water by Filtration/IMS/FA Available online: https: / / nepis.epa.gov /Exe/ZyNET.exe/P100J7G4.TXT?ZyActionD=ZyDocument\&Client=EPA\&Index=2011 + Thru $+2015 \&$ Docs $=\&$ Query $=\&$ Time $=\&$ EndTime $=\&$ SearchMethod $=1 \&$ TocRestrict $=$ n $\&$ Toc $=\&$ TocEntry $=\& Q$ Field $=\& Q$ Field Year $=$ $\& Q F i e l d M o n t h=\& Q F i e l d D a y=\& I n t Q F i e l d O p=0 \& E x t Q F i e l d O p=0 \& X m l Q u e r y=($ accessed on 23 March 2021).

33. Chalmers, R.; Johnston, R. Understanding the public health risks of Cryptosporidium in swimming pools: A transmission pathway approach. Perspect. Public Health 2018, 138, 238-240. [CrossRef]

34. Davies, A.P.; Campbell, B.; Evans, M.R.; Bone, A.; Roche, A.; Chalmers, R.M. Asymptomatic carriage of protozoan parasites in children in day care centers in the United Kingdom. Pediatr. Infect. Dis. J. 2009, 28, 838-840. [CrossRef] [PubMed]

35. Dufour, A.P.; Evans, O.; Behymer, T.D.; Cantu, R. Water ingestion during swimming activities in a pool: A pilot study. J. Water Health 2006, 4, 425-430. [CrossRef] [PubMed]

36. 2018 Model Aquatic Health Code. Available online: https://www.cdc.gov/mahc/pdf/2018-MAHC-Code-Clean-508.pdf (accessed on 23 March 2021).

37. Chappell, C.L.; Okhuysen, P.C.; Sterling, C.R.; DuPont, H.L. Cryptosporidium parvum: Intensity of infection and oocyst excretion patterns in healthy volunteers. J. Infect. Dis. 1996, 173, 232-236. [CrossRef] [PubMed]

38. Rendtorff, R.C.; Kashgarian, M. Stool patterns of healthy adult males. Dis. Colon Rectum 1967, 10, 222-228. [CrossRef] [PubMed]

39. Alansari, A.; Amburgey, J.; Madding, N. 2018 A quantitative analysis of swimming pool recirculation system efficiency. J. Water Health 2018, 16, 449-459. [CrossRef]

40. Falk, R.A.; Blatchley, E.R.; Kuechler, T.C.; Meyer, E.M.; Pickens, S.R.; Suppes, L.M. Assessing the Impact of Cyanuric Acid on Bather's Risk of Gastrointestinal Illness at Swimming Pools. Water 2019, 11, 1314. [CrossRef] 